\title{
Ekologia - program nauczania dla III klasy gimnazjalnej
}

\section{Człowiek i przyroda w świetle chrystologii ${ }^{1}$}

W programie trzeciej klasy gimnazjalnej pt. „W życiu i w prawdzie”, I. Być chrześcijaninem, w rozdz. IV. Jezus Chrystus, (...) Treści szczegółowe: „Jezus Chrystus - Słowo Wcielone”, p. 21 a, s. 38, należy ukazać człowieka i przyrodę w świetle chrystologii.

Już wiemy z wcześniejszych rozważań, że pierwszy człowiek podjął próbę poszukiwania celu ostatecznego poza Bogiem. Świadomie przeciwstawil się planom Stwórcy. Przez swój grzech zniszczył harmonię, jaka panowała między nim a całym stworzeniem². Skutki jego grzechu pierworodnego i grzechów uczynkowych odbiły się na jego życiu i losach biosfery. Pojawiła się w niej śmierć, zniewolenia, bóle porodowe i bunt przeklętej ziemi, która będzie rodzić cierpienie i osty a praca człowieka wiązać się będzie z trudem i potem. Stwierdza to Pismo św. słowami: „W pocie (...) oblicza twego będziesz musiał zdobywać pożywienie, póki nie wrócisz do ziemi, z której zostałeś wzięty" ${ }^{\prime \prime}$ Z racji popełnianych grzechów narastać będzie wrogość między przyrodą i człowiekiem. Gdy nie będzie umiał on żyć w pokoju z Bogiem, nie będzie pokoju na ziemi”"4. Pojawi się różnorakie spustoszenie ${ }^{5}$. W ten sposób stworzenie zostanie poddane różnorakiej marności ${ }^{6}$. Dziś o tym poddaniu świadczą w swych skutkach: kwaśne deszcze, smog, efekt cieplarniany, zubożenie warstwy ozonowej i działania toksycznych produktów chemicznych w licznych regionach świata. Można powiedzieć, iż żyjemy w spo-

1 Zob. J. Łukomski, Relacja człowieka do środowiska naturalnego w ujęciu chrześcijańskim, AVE, Radom 1997, s. 40-48.

2 Zob. Rdz 1, 28; 3, 14-19. Por. Jan Pawez II, Orędzie (...) na XXIII Światowy Dzień Pokoju (1 stycznia 1990) p. 3.

$3 \mathrm{Rdz} 3,19$.

4 Zob. JAN Pawee II, jw. p. 5.

5 Zob. Iz 33, 8; Oz 4, 1-3; Ps 107, 33.

6 Zob. Rz 8, 20. 
sób co najmniej niedorzeczny? ${ }^{7}$ Ten sposób życia i zespół wartości, które proponują uprzemysłowione środowiska, wydaje się być wrogi prawom przyrody. Liczne stworzenia jęczą i wzdychają w bólach rodzenia, oczekując objawienia się synów Bożych ${ }^{8}$.

Wydaje się, że w naszym odniesieniu się do własnej fizyczności oraz w naszych próbach zachowania właściwych związków ze światem przyrody pojawiły się bolesne pęknięcia, takie jak: współczesne okrucieństwo wobec poczętych dzieci, ludzi nieuleczalnie chorych i starych oraz zwierząt. Świadczy to o tym, że wielu utraciło świadomość, iż „natura jest sakramentalnym przedłużeniem Wcielenia".

\section{Wywyższenie czlowieka i kosmosu poprzez Wcielenie}

Syn Boży, przyjmując ludzką naturę jako narzędzie odkupienia, włączył się w historię człowieka i kosmosu. Wchodząc w jego dzieje stał się centralnym punktem historii zbawienia, jej początkiem i kresem. „Wcielenie Syna Bożego było ostateczną racja stworzenia człowieka i świata"10. Jest ono jakby nowym tytułem godności kosmosu. Dzięki niemu bowiem został wywyższony nie tylko człowiek, ale także wszystkie jestestwa pozaludzkie wszechświata. „Fakt wcielenia i cielesny składnik egzystencji ziemskiej Chrystus rzuca jasne światło na zaciemnioną przez grzech wartość świata materialnego"11. Jego ludzkie ciało przekazuje życie Boże całemu stworzeniu. Jest bowiem zjednoczoną osobowo z Bogiem cząstką materii kosmosu. Ową cząstkę materii przyjął Chrystus, aby tworzyła Jego „historyczne” ciało. To zbudowane z pierwiastków ziemi ciało zostało przemienione na Górze Tabor, a potem ukrzyżowane. W tym ciele ukazywał się Chrystus swoim uczniom po zmartwychwstaniu.

Na gruncie realistycznej antropologii poznajemy, że ciało stanowi integralny element ludzkiej natury. Ta natura wraz z boską naturą oraz jednym istnieniem boskim stanowią jeden byt, osobę Chrystusa. „Natura ludzka, przyjęta przez Osobę Syna, nie może być ograniczona do pojedynczego człowieka - Jezusa. Jeśli ekologia uczy, że zadna jednostka nie jest samotna i wyobcowana, lecz stanowi cząstkę pajęczej sieci relacji rozciągającej się w kosmosie, to tym prawdziwsze jest to w odniesieniu do Jezusa z Nazaretu” ${ }^{\prime 2}$. Jest On połączony siecią różnorodnych relacji ze wszystkimi bytami naszego świata.

\footnotetext{
Zob. J. Łukomski, jw. s. 41.

Zob. Rz 8, 22.

Zob. S. Caldecot T, Prawa zwierzat?, „Communio” 1992, nr 6, s. 99.

10 P. GóralczYK, Ksztaltowanie postawy odpowiedzialności ekologicznej, „Communio” 1992, nr 6, s. 68.

1 P. GóralczyK, jw., s. 68.

12 S. Caldecot T, jw., s. 98.
} 
Co więcej, „w tajemnicy Wcielenia objawia się (...) sama konstytucja stworzenia jako bytu przyjmowanego i przyjętego, jako receptywność miłości"13. Boga Syna charakteryzuje receptywność, tzn. bycie miłością, którą otrzymuje. Podobnie stworzenie naznaczone jest w swej strukturze receptywnością miłości. To wszystko, czym ono jest, zostaje mu ofiarowane. Potwierdza to List do Kolosan, w którym stwierdza się, że wszystkie rzeczy zostały stworzone przez Chrystusa i ze względu na Niego ${ }^{14}$. W tajemnicy Chrystusa kosmos uczestniczy w przebóstwieniu człowieka. Świat materialny bowiem złączony jest ze światem ludzkim poprzez stwórcze i zbawcze akty Boga. Nie ma ludzkiego odkupienia, z którego wyłączona byłaby ziemia. Myśl patrystyczna zawiera przekonanie, ze Wcielenie Boga dokonuje przebóstwienia człowieka, a w nim materialnego świata ${ }^{15}$.

Pełna przemiana przyjętego we Wcieleniu ciała, jako cząstki materii, nastąpiła w zmartwychwstaniu Chrystusa. Wtedy stała się ona nieprzemijającą i osiągnęła uczestnictwo w wiecznej pełni życia Bożego. Zmartwychwstanie i uwielbione ciało Chrystusa stało się zaczątkiem nowej rzeczywistości - „nowych niebios i nowej ziemi”'16.

„Obietnica wiecznego trwania przemienionego świata, a w nim naturalnego środowiska czlowieka, wskazuje na wielką wartość przyrody, na przyszły kierunek jej rozwoju i na zadania człowieka wobec stworzeń. Między człowiekiem a jego przyrodniczym środowiskiem ma zachodzić współdziałanie, wzajemna pomoc w rozwoju, aż do pełni w Chrystusie" 17 .

\section{Krzyż Chrystusa wskazuje na solidarność Boga z człowiekiem i z całą przyrodą}

W związku z dziełem odkupienia, którego dokonał Chrystus, św. Paweł w Liście do Kolosan stwierdza: „Zechciał bowiem (Bóg) aby w Nim zamieszkała cała Pełnia, i aby przez Niego znów pojednać wszystko ze sobą: przez Niego - i, to co na ziemi, i to co w niebiosach, wprowadziwszy pokój przez krew Jego krzyża"18. O planie zbawienia i o misterium Chrystusa w Kościele mówi również List do Efezjan: „W Nim bowiem wybrał nas przed założeniem świata, abyśmy byli święci i nieskalani przed Jego obliczem. Z miłości przeznaczył nas dla siebie jako

\footnotetext{
13 J. J. Ferreira de Farias, Kosmos "przebóstwiony": przyczynek do sakramentalnej teologii świata, "Communio" 1992, nr 6, s. 130.

14 Zob. Kol 1, 16.

15 Zob. Z. ŚwIErczek, Ekologia-Kościól iśw. Franciszek, Kraków 1990, s. 53.

16 Zob. Ap 21, 1.

17 P. Góralczyk, jw., s. 69.

18 Kol 1, 19-20.
} 
przybranych synów (...). W Nim mamy odkupienie przez Jego krew - odpuszczenie występków, według bogactwa Jego łaski. Szczodrze ją na nas wylał (...), aby wszystko na nowo zjednoczyć w Chrystusie (...): to, co w niebiosach, i to co na ziemi"19.

Gdy Jezus Chrystus przyszedł na ziemię, ludzkość została odkupiona. Wcielony Bóg odnowił również i uzdrowił cały porządek świata rzeczy. Jego błogosławieństwo przywróciło boskie oblicze ludziom i innym bytom ${ }^{20}$. Chrystus jako twórcza zasada życia i harmonii dokonał w powszechnym zasięgu pojednania wszystkiego z Bogiem. Wyswobodzenie świata przez Jego krzyż wskazuje na Jego solidarność z ludzkością, z przyrodą, z całym stworzeniem, które zanika bez Stworzyciela ${ }^{21}$. Dzięki Niemu stworzenie, które niegdyś popadło w niewolę śmierci i zepsucia $(\mathrm{Rz} 8,21)$, zostało stworzone od nowa i otrzymało nowe ży$\mathrm{cie}^{22}$. On bowiem „przez swoją mękę na krzyżu wybawił nas od śmierci wiecznej, a zmartwychwstając dał nam wiekuiste życie"23. Złożył ofiarę za wszystkich, za każdego człowieka z jego ludzkim ciałem i naturalnym środowiskiem ${ }^{24}$.

Znamienne jest to, że ormiański ryt uzdrowienia roślin i stad ze wszystkich trapiących je dolegliwości uważa krzyż Chrystusa za źródło zbawienia nie tylko istot ludzkich, ale również roślin i zwierząt. Podkreśla jednak ten ryt, że dobro i odkupienie reszty świata, tzn. świata pozaludzkiego, zależy od przywrócenia boskiego obrazu w ludzkich osobach ${ }^{25}$. Na wschodnich zaś ikonach Narodzenia wól i osioł stoją przy żłóbku na pierwszym planie. Zwierzęta te przedstawiają się tutaj jako istoty, które mają jakiś udział w Przymierzu z Bogiem ${ }^{26}$. Mają one stałe miejsce w Bożym domostwie.

Na plan Boży, zapoczątkowany w Chrystusie, wpisuje się nasza historia i nasze związki ze środowiskiem naturalnym ${ }^{27}$. Dzieło odkupienia, którego On dokonał, miało zasadniczo na celu zbawienie wszystkich ludzi. Objęło jednak swym zasięgiem również odnowę całego porządku doczesnego. Odnowa ta polega na przepajaniu i doskonaleniu duchem ewangelicznym porządku spraw doczesnych. Chodzi więc o dwa porządki: duchowy i doczesny, które są tak zespolone w jednym Bożym planie, że „sam Bóg pragnie cały świat przekształcić w Chrystusie w nowe stworzenie, zaczątkowo już tu na ziemi, a w pełni w dniu ostatecznym"28.

19 Ef $1,4-10$.

20 Zob. J. Grześkowiak, Teologiczne przestanki odpowiedzialności za środowisko przyrodnicze, „Roczniki Teologiczno-Kanoniczne” 1980, nr 6, s. 19.

${ }_{21}$ Zob. Sobór Wat. II, Konstytucja duszpasterska o Kościele w świecie wspótczesnym, p. 36.

22 Zob. Ap 21, 5.

23 Druga prefacja na niedziele zwykłe. Mszał z czytaniami, Kraków 1986, s. 664.

24 Zob. C. Bart niK, Żyć w Stowie. Warszawa 1983, s. 228-229.

25 Zob. J. Łuкомsкi, Relacja człowieka do środowiska naturalnego, jw., s. 46.

${ }_{26}$ Zob. Rdz 9, 8-10.

27 Zob. Jan Pawee II, Sollicitudo rei socialis, p. 31.

${ }^{28}$ Sobór Wat. II, Dekret o apostolstwie świeckich, p. 5. 
W kwestii budzenia szacunku dla przyrody wymowny jest fakt wybrania przez Jezusa z Nazaretu chleba i wina, czyli przetworzonych ludzką pracą cząstek środowiska przyrodniczego, aby uczynić je swoim Ciałem i Krwią, które stanowią zbawienny pokarm wędrowców do domu Ojca.

\section{Pokój z Bogiem - pokój z calym stworzeniem}

W rozdziale szóstym pt. „Laboratorium wiary (...) Treści szczegółowe: Błogosławieni, którzy wprowadzają pokój”, p. 50, s. 43, należy zapoznać uczniów z treścią orędzia Jana Pawła II na XXIII Światowy Dzień Pokoju (1 stycznia 1990 roku).

Chrześcijańska wizja świata jest realistyczna i spójna. Opiera się na podstawach, które płyną z Objawienia i danych zdrowego rozumu. Należy ją ujawnić w perspektywie fundamentalnej prawdy, że istnieje stwórcza i pełna miłości obecność Boga we wszystkich Jego dziełach, z której wynika świętość świata zjawiskowego. Mówi o tym Księga Mądrości słowami: „Miłujesz bowiem wszystkie stworzenia, niczym się nie brzydzisz, co uczyniłeś, bo gdybyś miał coś w nienawiści, nie byłbyś tego uczynił. Jakżeby coś trwać mogło, gdybyś ty nie powołał do bytu? Jak by się zachowało, czego byś nie wezwał? Oszczędzasz wszystko, bo to wszystko Twoje..., (...) Bo we wszystkim jest Twoje nieśmiertelne tchnienie"29. Tym nieśmiertelnym tchnieniem podtrzymuje Stwórca wszystko w istnieniu i umożliwia działanie bytów stworzonych, które jest zgodne z ich naturą. A to jest naturą danego bytu, co w nim sprawia Bóg swą akcją stwórczą. Zgodnie z tym wszystkie byty świata przyrody maja swą trwałość, prawdę, dobroć, prawa i porządek, które winniśmy uszanować zgodnie z metodologią różnych dyscyplin naukowych ${ }^{30}$. Dodać należy, że prawa, które kierują przyrodą i rozumem człowieka są elementami tego samego planu Bożego ${ }^{31}$.

Wszystkie byty stworzone winny być przedmiotem naszej troski i szacunku. Mają bowiem swą niezbywalną dobroć. Wskazuje na to Objawienie i rozum. Księga Rodzaju w opisie stworzenia powtarza znamienne zdanie: „A Bóg widział, że były dobre". Zdanie to zostało ubogacone w opisie stworzenia człowieka:

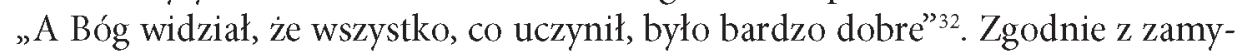
słem Stwórcy Adam i Ewa mają panować nad ziemią mądrze i z milością̧ tej myśli nawiązuje Księga Mądrości słowami: „W Mądrości swojej stworzyłeś

\footnotetext{
29 Mdr 11, 26-12, 1.

30 Zob. Sobór Wat. II, jw. (KDK), p. 36.

31 Zob. JAN XXIII, Pacem in terris, p. 1-8.

$32 \mathrm{Rdz} 1,31$.

33 Zob. Rdz 1, 28.
} 
człowieka, by panował nad stworzeniami, co przez Ciebie się stały, by władał światem w świętości i sprawiedliwości”'34.

Prawdę, że wszystko, co jest bytem, jest zarazem dobrem ukazuje także ludzki rozum w refleksji filozoficznej. Mówi on, że dobro i byt utożsamiają się (Bonum et ens convertuntur). Tym dobrem zdolni jesteśmy ubogacić nasze kruche i przygodne istnienie. Dlatego tak często dążymy do osób i rzeczy. Na każdym etapie posiadania wciąż chcemy (szukamy) czegoś więcej. Mamy nadzieję, że jakieś przygodne dobro zaspokoi nasze aspiracje. Żywimy przekonanie, że dobrem jest to, co siebie udziela na zewnątrz, co promieniuje, co emanuje, co się rozlewa. Realiści twierdzą, że dobro to cel wszelkiego dążenia (Bonum est quod omnia appetunt). Dobro i byt są wartościami równoważnymi i realnie tożsamymi. W związku z tym zauważyć należy, że dzieła Boże zachowują swą wartość, swą immanentną dobroć nawet wtedy, gdy staną się mniej użyteczne.

\section{Racjonalność przyrody mówi o zamyśle Stwórcy}

„Kto pokornie i wytrwale usiłuje zbadać tajniki rzeczy, prowadzony jest niejako, choć nieświadomie ręką Boga, który wszystko utrzymując sprawia, że rzeczy są tym, czym są"35. Rozpoznaje też, że ten sam Bóg, którego poznajemy przez Objawienie, jest tym, który odcisnął swoje ślady w wielkiej księdze natury. Dzięki temu Jego przymioty, potęga oraz bóstwo „stają się widzialne dla umysłu przez jego dzieła"36.

Każdy, kto prowadzi badania naukowe lub techniczne, „przyjmuje jako przesłankę (...) pogląd, że świat nie jest chaosem, ale kosmosem, to znaczy, że istnieje w nim ład i rządzą nim prawa natury, które można ogarnąć myślą" ${ }^{37}$. Dziwne jest to, że ten świat przyrody jawi się naszym oczom jako suma kół, spiral, łuków lub ich fragmentów, które są przedziwnie powiązane i ukształtowane płasko lub w postaci brył ${ }^{38}$. Dają się one ogarnąć myślą, to znaczy poznać rozumowo, ponieważ byt jest racjonalny, przyporządkowany intelektowi. O tej jego racjonalności świadczy historyczny rozwój nauk, który stanowi progresywne odkrywanie tego, co już istnieje, a dotychczas nie było znane. W tym, co jest, odczytujemy zamysł Absolutu, Jego pomysł, plan, według którego wszystko zostało ukonstytuowane

34 Mdr 9, 1-3.

35 Sobór Wat. II, Konstytucja duszpasterska o Kościele w świecie wspólczesnym p. 59.

$36 \mathrm{Rz} 1,20$.

37 Jan PaweŁ II, Sprawa Galileusza lekcja dla wspólczesnych, „L'Osservatore Romano” 1993, nr 1, s. 26.

38 Zob. J. JANECKI, Natura jest krzywa, „Człowiek i Przyroda” 1995, nr 3, s. 37. Linie proste występują w dziełach człowieka. 
aktem stwórczym. Odkrywanie to nie polega na tym, że uczeni tworzą prawa przyrody, lecz na tym, że odkrywają stałe relacje między zjawiskami, czyli to, co już istnieje jako zamyst i plan Twórcy kosmosu. Zechciejmy zauważyć, że obecnie rozwój kosmologii relatywistycznej „ukazuje zagadkową racjonalność przyrody, która przykuwała uwagę pitagorejczyków czy Keplera w koncepcji jej matematyczności, inspirowała teorię jej inteligibilności w ujęciach scholastyków i zadziwiała koncepcją harmonii świata Leibniza czy Teiharda de Chardin" ${ }^{39}$.

\section{Kryzys wartości moralnych wyraża się w degradacji środowiska naturalnego}

Sprzeciw wobec planów Boga Stwórcy sprawia, że człowiek, który został powołany do udziału w dziele stwórczym, wprowadza w świat nieporządek, popada W niewolę śmierci i zepsucia ${ }^{40}$. Jednocześnie objawia się prawda, że gdy człowiek nie żyje w pokoju z Bogiem, nie ma pokoju na ziemi ${ }^{41}$. Jawią się róźne znaki kryzysu ekologicznego, takie jak: niszczenie warstwy ozonowej, efekt cieplarniany, kwaśne deszcze, nieracjonalna eksploatacja zasobów ziemi, niekontrolowane wycinanie lasów, produkcja broni chemicznych i bakteriologicznych. W ten sposób wynaturzony światopogląd, związany z pogardą dla godności człowieka, rodzi zachowania, które są sprzeczne z zasadami ochrony środowiska i ludzkiego życia. Zapomniano o tym, że „szacunek dla życia, a przede wszystkim dla ludzkiej godności, jest podstawową zasadą zdrowego postępu ekonomicznego, przemysłowego i naukowego"42.

\section{Pilna potrzeba solidarności}

W obliczu ludzkiej zachłanności i zbiorowego egoizmu, który sprzeciwia się porządkowi stworzenia, konieczne jest wdrożenie wszystkich ludzi do poszanowania praw natury, jej racjonalnych struktur i równowagi ekosystemów. Konieczne jest uznanie $w$ wymiarze indywidualnym i społecznym zasady powszechnego przeznaczenia dóbr, która jest kamieniem węgielnym porządku ekologicznego. Ziemia jest bowiem zasadniczo wspólnym dziedzictwem, którego owoce winny służyć wszystkim ludziom, bez względu na pochodzenie etniczne, rasę czy przynależność narodową ${ }^{43}$ W związku z tym wskazane jest stworzenie

\footnotetext{
39 J. ŻycıŃski, Granice racjonalności. Eseje z filozofi nauki, PWN, Warszawa 1993, s. 190.

40 Zob. Rz 8, 21; Oz 4, 3 .

${ }^{41}$ Zob. Jan PaweŁ II, Orędzie (...) na XXIII Światowy Dzień Pokoju, p. 5.

42 Jan PAWEe II, jw. p. 7.

${ }^{43}$ Zob. Sobór Wat. II, jw., p. 69.
} 
lepszego systemu koordynacji międzynarodowej w dziedzinie rozporządzania zasobami ziemi. Wszystkie państwa winny być coraz bardziej solidarne w działaniach na rzecz pokojowego oraz zdrowego rozwoju środowiska naturalnego i społecznego. Z tej racji muszą zniknąć strukturalne formy ubóstwa w świecie. Nie można też tolerować manipulowania środowiskiem w celach wrogich człowiekowi, co wyraża się w produkcji broni biologicznej i chemicznej.

W wielu kręgach społecznych konieczna jest zmiana stylu życia, odejście od konsumizmu i przyjęcie zasady ascezy konsumpcji, aby przez to umożliwić rozwiązanie kwestii ekologicznej w skali globalnej. Potrzebne jest również nawrócenie w sposobie myślenia i postępowania w duchu odpowiedzialności ekologicznej. Zły stan świadomości sozologicznej i postaw ekologicznych w wielu środowiskach stanowi przejaw głębokiego kryzysu moralnego współczesnego człowieka. O tym kryzysie świadczy także przede wszystkim brak szacunku dla niezbywalnej godności osoby ludzkiej i jej życia. W tym kontekście można zapytać: Jak można mówić o ochronie środowiska naturalnego, gdy nie szanuje się życia ludzkiego?

Z ziemi i z atmosfery płynie do nas szczególne przesłanie: „Porządek, który panuje we wszechświecie, wymaga szacunku; osoba ludzka, obdarzona możliwością wolnego wyboru, jest głęboko odpowiedzialna za zachowanie tego porządku, również dla dobra przyszłych pokolen'" ${ }^{4}$. Tym bardziej więc ci, którzy wierzą w Boga Stwórcę i rozpoznają racjonalność Jego dzieła, winni traktować swoją odpowiedzialność za wewnętrzny lad ekosystemów i swoje obowiązki względem przyrody, którą należy z nakazu Boga „uprawiać” (przekształcać) w mądrości i sprawiedliwości, jako element swojej wiary. „Biedaczyna z Asyżu daje nam świadectwo, że w pokoju z Bogiem możemy lepiej poświęcić się budowaniu pokoju z calym stworzeniem" ${ }^{\prime 4}$.

\section{Ecology - religion teaching programme for the III class of preparatory school}

\section{SUMMARY}

The article presents analysises of the following issues from the ecological programme for the III class of preparatory school: human and nature in the light of christology, the elevation of human and universe by the Incarnation, Christs's cross points the solidarity of God with human and whole nature, peace with God, peace with every creature, rationality of the nature tells about Creator's idea, crisis of moral values finds expression in degradation of natural environment, urgent need of solidarity.

44 JAN PAWE€ II, Orędzie (...) na XXIII..., jw., „L'Osservatore Romano” 1989, nr 12 bis, p. 15.

45 Tamże, p. 16. 